\title{
Pengaruh Insentif Terhadap Kinerja Karyawan Pada Hotel Mexsicana Kota Jambi
}

\author{
Said Almaududi, Muhammad Syukri, Camelia Puji Astuti \\ Fakultas Ekonomi Universitas Batanghari Jambi \\ Correspondence email: saidalmaududi@gmail.com
}

\begin{abstract}
The purpose of this study is to find out and describe the Incentives and Employee Performance at the Jambi City Mexsicana Hotel, and to determine the effect of the Incentives on the Employee Performance at the Jambi City Mexsicana Hotel. The type of data needed and collected in this study is quantitative data. The object of this study is the employee of the Mexsicana Hotel Jambi City. Sources of data in this study were employees of the City of Mexsicana Hotel Jambi taken through interviews by distributing questionnaires, data, and information obtained analyzed descriptively, to analyze employee responses to incentives for performance using a 5-choice scale. Based on the results of the regression analysis it was concluded that the regression equation $Y=32.316+0.154 X+e$. The correlation coefficient $(R)$ of the independent variable is 0.767 . This value indicates that the incentive relationship on Mexsicana Hotel Jambi Erat employees' performance is 0.767 . While the coefficient of determination (R2) of 0.589 it means that the variation of change in $Y$ is influenced by changes in $X$ by 58.9\%. So the magnitude of the effect of incentives on the performance of employees of the City of Mexsicana Hotel Jambi is 58.9\% while the remaining 41.1\% is influenced by other factors outside this study. Partially, there is an effect of incentives on the performance of Mexicicana Hotel Jambi City employees. This is indicated by the value of incentive thitung of 2.171 and ttable of 2.034 from the comparison results it can be seen that tcount is greater than ttable (thitung > ttable). Then $\mathrm{HO}$ is rejected and Ha is accepted. By comparing the magnitude of the level of significance ( sig) of research with a significant level of 0.05 then $0.002<0.05$ so that it can be said that there is a significant effect between incentives on the performance of employees of Mexsicana Hotel Jambi City. For the management of the City of Mexsicana Hotel Jambi, it is hoped that incentives can be noticed and increased in terms of employee performance. So that incentives for employee performance can be better in the future. Next researchers are expected to be able to conduct research using different variables from the variables studied.
\end{abstract}

Keyword : Incentive, Performance

\section{Pendahuluan}

Sumber daya manusia merupakan salah satu faktor produksi yang sangat penting di dalam menjalankan roda kegiatan dalam sebuah perusahaan. Keberhasilan sebuah perusahaan untuk mencapai tujuan organisasi sangat tergantung pada kemampuan sumber daya manusia dalam memberdayakan sumber daya yang ada serta memanfaatkan semaksimal mungkin potensi sumber daya tersebut. Manusia merupakan satu-satunya sumber daya yang memiliki akal, perasaan, keinginan, keterampilan, pengetahuan, dorongan, daya dan karya. Semua potensi sumber daya manusia tersebut berpengaruh terhadap upaya organisasi dalam mencapai tujuan. Betapa majunya teknologi, perkembangan informasi, tersedianya modal dan memadainya bahan, jika tanpa sumber daya manusia sulit bagi organisasi tersebut untuk mencapai tujuannya.

Manajemen sumber daya manusia merupakan satu bidang manajemen yang khusus mempelajari hubungan dan peranan manusia dalam organisasi. Hal ini disebabkan manajemen sumber daya manusia mengatur tenaga kerja yang ada di dalam organisasi, sehingga terwujud tujuan organisasi dan kepuasan kerja karyawan. Manajemen sumber daya manusia juga dapat menghasilkan kinerja yang baik dalam sebuah perusahaan dengan cara penilaian, pemberian balas jasa dalam setiap individu anggota organisasi sesuai dengan kemampuan kerjanya. Manajemen sumber daya manusia adalah ilmu dan seni mengatur hubungan dan peranan tenaga kerja agar efektif dan efisien membantu terwujudnya tujuan perusahaan, karyawan dan masyarakat (Hasibuan, 2013). Sedangkan menurut Flippo dalam Hasibuan (2013) manajemen sumber daya manusia adalah perencanaan, pengorganisasian, pengarahan dan pengendalian dari pengadaan, pengembangan, kompensasi, pengintegrasian, pemeliharaan dan pemberhentian karyawan dengan maksud terwujudnya tujuan perusahaan, individu, karyawan dan masyarakat.

Untuk dapat melaksanakan tugas dan fungsinya dengan sebaik mungkin maka dibutuhkan kinerja yang baik dari sehingga terciptanya hasil kerja yang baik juga bagi perusahaan. Dari kinerja yang baik, karyawan dapat meningkatkan penjualan yang mungkin melampaui target. Dari Hasil penjualan yang telah melampaui target membuat karyawan mendapatkan insentif dari hasil penjualan tersebut. Sehingga dengan adanya pemberian insentif yang diberikan kepada karyawan membuat kinerja yang dihasilkan pun sangat baik bagi perusahaan. Pemberian insentif merupakan salah satu hal pokok yang harus diperhatikan oleh perusahaan. Semangat tidaknya karyawan bisa juga disebabkan oleh besar kecilnya insentif yang diterima. Apabila karyawan tidak mendapatkan insentif yang sesuai dengan besarnya pengorbanan dalam bekerja, maka karyawan tersebut cenderung malas bekerja dan tidak bersemangat yang ada akhirnya mereka bekerja semaunya tanpa ada motivasi yang tinggi. 
Menurut Hasibuan (2013), mengemukakan bahwa Insentif adalah tambahan balas jasa yang diberikan kepada karyawan tertentu yang prestasinya di atas prestasi standar. Insentif ini merupakan alat yang dipergunakan pendukung prinsip adil dalam pemberian kompensasi. Insentif menurut Flippo dalam Hasibuan (2009) Incentive is defined as the adeque and equitable renumeration of personnel for their constribution to organizational objectives. Dengan adanya pemberian insentif yang tepat serta cara kerja yang baik Sehingga ke depannya, proses kerja organisasi dapat berjalan sesuai tujuan organisasi. Para ahli diatas semakin menjelaskan bahwa insentif merupakan pemberian uang di luar gaji yang dilakukan oleh pemimpin organisasi sebagai pengakuan terhadap kinerja karyawan kepada perusahaan. Apabila insentif yang diberikan perusahaan sudah tepat, maka insentif yang diberikan akan meningkatkan kinerja karyawan tersebut.

Notoatmodjo (2009) mengatakan bahwa kinerja adalah unjuk kerja yang merupakan hasil kerja dihasilkan oleh karyawan atau prilaku nyata yang ditampilkan sesuai dengan perannya dalam organisasi. Armstrong dan Baron (dalam Wibowo 2009) menjelaskan bahwa kinerja (performance) adalah tentang melakukan pekerjaan dan hasil yang dicapai dari pekerjaan tersebut.Kinerja merupakan hasil pekerjaan yang mempunyai hubungan kuat dengan tujuan strategis organisasi, kepuasan konsumen dan memberikan kontribusi ekonomi. Para ahli diatas semakin menjelaskan Kinerja merupakan hasil dan perilaku kerja yang dihasilkan oleh seorang karyawan sesuai dengan perannya dalam organisasi dalam suatu periode tertentu. Kinerja karyawan yang baik adalah salah satu faktor yang sangat penting dalam upaya untuk meningkatan produktivitas. Oleh karena, itu salah satu cara terbaik untuk meningkatkan kinerja karyawan adalah dengan memberikan insentif kepada karyawan agar dapat memotivasi sehingga karyawan lebih meningkatkan lagi kinerjanya, sehingga kinerjanya meningkat dan perusahaan pun mampu menghasilkan produk dengan harga yang kompetitif.

Tidak tercapainya jumlah target penjualan jasa kamar pada Hotel Mexsicana Kota Jambi dipengaruhi oleh beberapa faktor, yaitu faktor intern dan faktor ekstern. Faktor intern biasa disebabkan karena kurangnya fasilitas dan pelayanan yang diberikan dan kurangnya promosi dari pihak hotel kepada konsumen, sehingga konsumen tidak mengetahui keunggulan atau keistimewaan yang dimiliki oleh Hotel Mexsicana Kota Jambi. Sedangkan faktor ekstern dapat disebabkan semakin banyaknya perusahaan sejenis, sehingga tingkat persaingan semakin ketat bagi Hotel Mexsicana Kota Jambi. Untuk menghadapi persaingan yang semakin ketat ini dibutuhkan suatu kebijaksanaan hotel dalam mengambil langkah-langkah konkrit dan tepat untuk mengatasinya. Tujuan penelitian ini adalah untuk mengetahui pengaruh insentif terhadap kinerja karyawan pada Hotel Mexsicana Kota Jambi.

\section{Tinjauan Pustaka \\ Manajemen Sumber Daya Manusia (SDM)}

Manajemen sumber daya manusia adalah ilmu dan seni mengatur hubungan dan peranan tenaga kerja agar efektif dan efisien membantu terwujudnya tujuan perusahaan, karyawan dan masyarakat (Hasibuan, 2013). Sedangkan menurut Flippo dalam Hasibuan (2013) manajemen sumber daya manusia adalah perencanaan, pengorganisasian, pengarahan dan pengendalian dari pengadaan, pengembangan, kompensasi, pengintegrasian, pemeliharaan dan pemberhentian karyawan dengan maksud terwujudnya tujuan perusahaan, individu, karyawan dan masyarakat. Menurut Yoder dalam Hasibuan (2013) manajemen sumber daya manusia adalah penyedia kepemimpinan dan pengarahan para karyawan dalam pekerjaan atau hubungan kerja mereka. Menurut pendapat Miner dan Mary Green Miner dalam Hasibuan (2013), manajemen sumber daya manusia adalah suatu proses pengembangan, menerapkan dan menilai kebijakan-kebijakan, prosedur-prosedur, metode-metode dan program-program yang berhubungan dengan individu karyawan dalam organisasi. Bermacam-macam pendapat tentang pengertian manajemen sumber daya manusia, antara lain adanya yang menciptakan Human Resources, ada yang mengartikan sebagai man power management serta ada yang menyertakan dengan pengertian manajemen sumber daya manusia sebagai personal (personalia, kepegawaian, dan sebagainya).

\section{Insentif}

Insentif sebagai sarana motivasi yang mendorong para karyawan untuk bekerja dengan kemampuan yang optimal, yang dimaksudkan sebagai pendapatan ekstra di luar gaji atau upah yang telah ditentukan. Pemberian insentif dimaksudkan agar dapat memenuhi kebutuhan para karyawan dan keluarga mereka. Istilah sistem insentif pada umumnya digunakan untuk menggambarkan rencana-rencana pembayaran upah yang dikaitkan secara langsung atau tidak langsung dengan berbagai standar kinerja karyawan atau profitabilitas organisasi.

Kompensasi dan insentif mempunyai hubungan yang sangat erat, di mana insentif merupakan komponen dari kompensasi dan keduanya sangat menentukan dalam pencapaian tujuan dan sasaran organisasi secara keseluruhan. Insentif dapat dirumuskan sebagai balas jasa yang memadai kepada karyawan yang prestasinya melebihi standar yang telah ditetapkan. Insentif merupakan suatu faktor pendorong bagi karyawan untuk bekerja lebih baik agar kinerja pegawai dapat meningkat. Menurut Hasibuan (2013), mengemukakan bahwa Insentif adalah tambahan balas jasa yang diberikan kepada karyawan tertentu yang prestasinya di atas prestasi standar. Insentif ini merupakan alat yang dipergunakan pendukung prinsip adil dalam pemberian kompensasi. Insentif menurut Flippo dalam Hasibuan (2009) 
Incentive is defined as the adeque and equitable renumeration of personnel for their constribution to organizational objectives). Sedangkan menurut Sikula dalam Hasibuan (2009) Incentive a reward payment or reimbursement for services rendered.

Jadi menurut pendapat-pendapat para ahli di atas dapat penulis simpulkan, bahwa insentif adalah dorongan pada seseorang agar mau bekerja dengan baik dan agar lebih dapat mencapai tingkat kinerja yang lebih tinggi sehingga dapat membangkitkan gairah kerja dan motivasi seorang karyawan. Di mana pada prinsipnya pemberian insentif menguntungkan kedua belah pihak. Perusahaan mengharapkan adanya kekuatan atau semangat yang timbul dalam diri penerima insentif yang mendorong mereka untuk bekerja dengan lebih baik dalam arti lebih produktif agar tujuan yang ingin dicapai oleh perusahaan dapat terpenuhi sedangkan bagi karyawan sebagai salah satu alat pemuas kebutuhannya

Menurut Hasibuan (2013), Indikator-indikator insentif, yaitu :

1. Kinerja, sistem insentif dengan cara ini langsung mengkaitkan besarnya insentif dengan kinerja yang telah ditunjukkan oleh pegawai yang bersangkutan. Berarti besarnya insentif tergantung pada banyak sedikitnya hasil yang dicapai dalam waktu kerja pegawai. Cara ini dapat diterapkan apabila hasil kerja diukur secara kuantitatif, memang dapat dikatakan bahwa dengan cara ini dapat mendorong pegawai yang kurang produktif menjadi lebih produktif dalam bekerjanya. Di samping itu juga sangat menguntungkan bagi pegawai yang dapat bekerja cepat dan berkemampuan tinggi. Sebaliknya sangat tidak favourable bagi pegawai yang bekerja lamban atau pegawai yang sudah berusia agak lanjut.

2. Lama Kerja, besarnya insentif ditentukan atas dasar lamanya pegawai melaksanakan atau menyelesaikan suatu pekerjaan. Cara perhitungannya dapat menggunakan per jam, per hari, per minggu ataupun per bulan. Umumnya cara yang diterapkan apabila ada kesulitan dalam menerapkan cara pemberian insentif berdasarkan kinerja.

3. Senioritas, sistem insentif ini didasarkan pada masa kerja atau senioritas pegawai yang bersangkutan dalam suatu organisasi. Dasar pemikirannya adalah pegawai senior, menunjukkan adanya kesetiaan yang tinggi dari pegawai yang bersangkutan pada organisasi di mana mereka bekerja. Semakin senior seorang pegawai semakin tinggi loyalitasnya pada organisasi, dan semakin mantap dan tenangnya dalam organisasi. Kelemahan yang menonjol dari cara ini adalah belum tentu mereka yang senior ini memiliki kemampuan yang tinggi atau menonjol, sehingga mungkin sekali pegawai muda (junior) yang menonjol kemampuannya akan dipimpin oleh pegawai senior, tetapi tidak menonjol kemampuannya. Mereka menjadi pimpinan bukan karena kemampuannya tetapi karena masa kerjanya. Dalam situasi demikian dapat timbul di mana para pegawai junior yang energik dan mampu tersebut keluar dari perusahaan/instansi.

4. Kebutuhan, cara ini menunjukkan bahwa insentif pada pegawai didasarkan pada tingkat urgensi kebutuhan hidup yang layak dari pegawai. Ini berarti insentif yang diberikan adalah wajar apabila dapat dipergunakan untuk memenuhi sebagian kebutuhan pokok, tidak berlebihan namun tidak berkekurangan. Hal seperti ini memungkinkan pegawai untuk dapat bertahan dalam perusahaan/instansi.

5. Keadilan dan Kelayakan Keadilan, dalam sistem insentif bukanlah harus sama rata tanpa pandang bulu, tetapi harus terkait pada adanya hubungan antara pengorbanan (input) dengan (output), makin tinggi pengorbanan semakin tinggi insentif yang diharapkan, sehingga oleh karenanya yang harus dinilai adalah pengorbanannya yang diperlukan oleh suatu jabatan. Input dari suatu jabatan ditunjukkan oleh spesifikasi yang harus dipenuhi oleh orang yang memangku jabatan tersebut. Oleh karena itu semakin tinggi pula output yang diharapkan. Output ini ditunjukkan oleh insentif yang diterima para pegawai yang bersangkutan, di mana di dalamnya terkandung rasa keadilan yang sangat diperhatikan sekali oleh setiap pegawai penerima insentif tersebut. Disamping masalah keadilan dalam pemberian insentif tersebut perlu pula diperhatikan masalah kelayakan. Layak pengertiannya membandingkan besarnya insentif dengan perusahaan lain yang bergerak dalam bidang usaha sejenis. Apabila insentif didalam perusahaan yang bersangkutan lebih rendah dibandingkan dengan perusahaan lain, maka perusahaan/instansi akan mendapat kendala yakni berupa menurunnya kinerja pegawai yang dapat diketahui dari berbagai bentuk akibat ketidakpuasan pegawai mengenai insentif tersebut.

6. Evaluasi jabatan, evaluasi jabatan adalah suatu usaha untuk menentukan dan membandingkan nilai suatu jabatan tertentu dengan nilai jabatan-jabatan lain dalam suatu organisasi. Ini berarti pula penentuan nilai relatif atau harga dari suatu jabatan guna menyusun rangking dalam penentuan insentif.

\section{Kinerja}

Kinerja adalah hasil kerja yang dicapai seseorang dalam melaksanakan tugas-tugasnya atas kecakapan, usaha dan kesempatan. Berdasarkan paparan diatas kinerja adalah suatu hasil yang dicapai seseorang dalam melaksanakan tugas-tugas yang didasarkan atas kecakapan, pengalaman dan kesungguhan serta waktu menurut standar dan kriteria yang telah ditetapkan sebelumnya (Hasibuan, 2013). Kinerja dalam organisasi merupakan jawaban dari berhasil atau tidaknya tujuan organisasi yang telah ditetapkan. Kesan-kesan buruk organisasi yang mendalam berakibat dan mengabaikan tanda-tanda peringatan adanya kinerja yang merosot. Menurut Mangkunegara (2010) Kinerja (prestasi 
kerja) adalah hasil kerja secara kualitas dan kuantitas yang dicapai oleh sesorang pegawai dalam melaksanakan tugasnya sesuai dengan tanggung jawab yang diberikan kepadanya.

Armstrong dan Baron dalam Wibowo (2009) menjelaskan bahwa kinerja (performance) adalah tentang melakukan pekerjaan dan hasil yang dicapai dari pekerjaan tersebut.Kinerja merupakan hasil pekerjaan yang mempunyai hubungan kuat dengan tujuan strategis organisasi, kepuasan konsumen dan memberikan kontribusi ekonomi. Pendapat lainnya mengenai kinerja yang dikemukakan oleh Hugh J. Arnold dan Daniel C Feldman dalam Lamatenggo (2012) mengatakan bahwa kinerja adalah serangkaian perilaku dan kegiatan secara individual sesuai dengan harapan atau tujuan organisasi. Sedangkan Ivancevich, Donnelly dan Gibson dalam Wibowo (2009) mengatakan bahwa kinerja adalah ukuran utama keberhasilan suatu organisasi dan tanggung jawabnya. Pendapat ini menegaskan bahwa kinerja merupakan standar organisasi untuk mencapai keberhasilan yang menjadi tanggung jawabnya.

Dari beberapa pengertian kinerja menurut para ahli tersebut dapat disimpulkan bahwa kinerja karyawan adalah hasil kerja yang dilakukan oleh seseorang dalam suatu organisasi agar tercapai tujuan yang diinginkan suatu organisasi dan meminimalisir kerugian. Atau kinerja adalah kesediaan seseorang atau kelompok orang untuk melakukan sesuatu kegiatan dan menyempurnakannya sesuai dengan tanggung jawabnya dengan hasil seperti yang diharapkan.

Lalu selanjutnya menurut Mangkunegara (2010) berpendapat bahwa ada hubungan yang positif antara motif berprestasi dengan pencapaian kerja. Motif berprestasi adalah suatu dorongan dalam diri seseorang untuk melakukan sesuatu kegiatan atau tugas dengan sebaik-baiknya agar mampu mencapai prestasi kerja (kinerja) dengan predikat terpuji.

Menurut Mangkunegara (2010) ada 3 faktor yang berpengaruh terhadap kinerja: (1) faktor individu : kemampuan, ketrampilan, latar belakang keluarga, pengalaman kerja, tingkat sosial dan demografi seseorang; (2) faktor psikologis : persepsi, peran, sikap, kepribadian, motivasi dan kepuasan kerja; dan Faktor organisasi : struktur organisasi, desain pekerjaan, kepemimpinan, sistem penghargaan (reward system).

Menurut Mangkunegara (2010) menyatakan bahwa faktor yang memengaruhi kinerja antara lain :

1. Faktor kemampuan. Secara psikologis kemampuan (ability) pegawai terdiri dari kemampuan potensi (IQ) dan kemampuan realita (pendidikan). Oleh karena itu pegawai perlu dtempatkan pada pekerjaan yang sesuai dengan keahlihannya.

2. Faktor motivasi. Motivasi terbentuk dari sikap (attiude) seorang pegawai dalam menghadapi situasi (situasion) kerja. Motivasi merupakan kondisi yang menggerakkan diri pegawai terarah untuk mencapai tujuan kerja. Sikap mental merupakan kondisi mental yang mendorong seseorang untuk berusaha mencapai potensi kerja secara maksimal.

Selanjut Mangkunegara (2010: 95), mengemukakan 6 (enam) karakterisitik dari seseorang memiliki motif yang tinggi yaitu : (1) Memiliki tanggung jawab tinggi; (2) Berani mengambil resiko; (3) Memiliki tujuan yang realistis; (4) Memiliki rencana kerja yang meneyeluruh dan berjuang untuk merealisasikan tujuan; (5) Memanfaatkan umpan balik yang konkrit dalam seluruh kegiatan kerja yang dilakukan; DAN (6) Mencari kesempatan untuk merealisasikan rencana yang telah diprogramkan.

Menurut Mangkunegara (2010: 132) yang menjadi indikator dalam variabel kinerja sebagai berikut :

1. Kualitas kerja, Seberapa baik seorang karyawan mengerjakan apa yang seharusnya dikerjakan.

2. Kuantitas kerja, Seberapa lama seseorang pegawai bekerja dalam satu harinya. Kuantitas kerja ini dapat dilihat dari kecepatan kerja setiap pegawai itu masing-masing.

3. Pelaksanaan tugas, Seberapa jauh karyawan mampu melakukan pekerjaannya dengan akurat atau tidak ada kesalahan

4. Tanggung jawab, Kesadaran akan kewajiban melakukan pekerjaan dengan akurat atau tidak ada kesalahan.

\section{Pengaruh Insentif terhadap Kinerja}

Sebuah organisasi atau perusahaan membutuhkan karyawan yang mampu memberikan hasil kerja atau output agar tujuan dari perusahaan tersebut bisa tercapai. Hasil kerja atau kinerja setiap karyawan berbeda-beda dan hal tersebut dipengaruhi beberapa faktor. Salah satu faktor tersebut adalah insentif mampu mendorong atau memotivasi karyawan untuk bekerja lebih baik, semakin baik kinerja karyawan maka semakin tinggi pula insentif yang diberikan. Karena hal tersebut karyawan akan berusaha untuk meningkatkan kinerja mereka agar insentif yang diterima meningkat. Hal ini didukung oleh pendapat Wibowo (2009) insentif mempunyai hubungan dengan kinerja karyawan karena setiap pekerjaan yang telah memberikan kinerja terbaiknya pasti mengharapkan imbalan disamping gaji atau upah sebagai tambahan berupa insentif atas perestasi yang diberikannya terhadap perusahaan

Menurut Handoko (2015) Istilah sistem insentif pada umumnya digunakan untuk menggambarkan rencanarencana pembayaran upah yang dikaitkan secara langsung atau tidak langsung dengan berbagai standar produktivitas atau kinerja karyawan atau profitabilitas organisasi atau kedua kriteria tersebut. Bagi karyawan insentif akan 
memotivasi atau memicu semangat karyawan supaya memberikan hasil semaksimal mungkin agar insentif yang mereka terima dapat maksimal. Bagi perusahaan atau organisasi insentif berguna untuk menjaga karyawan yang memiliki kualitas baik dalam bekerja di perusahaan atau organisasi tersebut. Oleh kaarena itu pemberian insentif tidak dapat diberikan asal-asalan harus memperhatikan kinerja dari karyawan tersebut.

\section{Hipotesis}

Menurut Sugiyono (2014) Hipotesis merupakan jawaban sementara terhadap rumusan masalah penelitian, dimana rumusan masalah penelitian telah dinyatakan dalam bentuk pertanyaan. Hipotesis dikatakan sementara karena jawaban yang diberikan baru didasarkan pada teori. Berdasarkan pada kajian teori dan perumusan masalah, serta kerangka berfikir tersebut di atas, maka hipotesis yang diajukan adalah:

1. Diduga Insentif dan Kinerja Karyawan pada Hotel Mexsicana Kota Jambi tinggi.

2. Diduga Insentif berpengaruh signifikan terhadap Kinerja Karyawan Pada Hotel Mexsicana Kota Jambi

\section{Metode}

Jenis data yang diperlukan dan dikumpulkan dalam penelitian ini ialah data kuantitatif. Menurut Soewandi (2012) Data kuantitatif sendiri ialah fakta atau keterangan dinyatakan dalam bentuk bilangan atau skala numeric (angka). Objek penelitian ini adalah karyawan Hotel Mexsicana Kota Jambi. Sumber data dalam penelitian ini adalah karyawan Hotel Mexsicana Kota Jambi yang diambil melalui wawancara dengan menyebar kuesioner, data, dan informasi yang diperoleh dianalisis secara deskriptif, untuk menganalisis respon pegawai mengenai insentif terhadap kinerja yang menggunakan skala 5 pilihan.

\section{Analisis Regresi Linier Sederhana}

Analisis regresi linier sederhana adalah hubungan secara linier antara dua atau lebih variabel independen (X) dengan variabel dependen $(\mathrm{Y})$. Analisis ini untuk mengetahui arah hubungan antara variabel independen dengan variabel dependen apakah masing-masing variabel independen berhubungan positif atau negatif dan untuk memprediksi nilai dari variabel dependen apabila nilai variabel dependen mengalami kenaikan atau penurunan. Data yang digunakan biasanya berskala interval atau rasio.

$\mathrm{Y}=\mathrm{a}+\beta \mathrm{X}+\mathrm{e}$

$\mathrm{Y}=$ Kinerja; $\mathrm{a}=$ Nilai Konstanta; $\beta=$ Koefisien Variabel Independen; $\mathrm{X}=$ Insentif; $\mathrm{e}=$ Error

\section{Koefisien Determinasi}

Analisis determinasi digunakan untuk mengetahui persentase sumbangan pengaruh variabel bebas secara bersama-sama terhadap variabel tergantung. Koefisien determinasi menunjukkan seberapa besar persentase variasi variabel bebas yang digunakan dalam model mampu menjelaskan variasi variabel tergantung (Priyanto, 2013). Besarnya koefisien determinasi dari 0 sampai dengan 1. Semakin mendekati 0 besarnya koefisien determinasi suatu persamaan regresi, maka semakin kecil pula pengaruh semua variabel independen terhadap nilai variabel dependen. Sebaliknya, semakin mendekati 1 besarnya koefisien determinasi suatu persamaan regresi, maka semakin besar pula pengaruh semua variabel independen terhadap variabel dependen (Algifari, 2009).

\section{Pengujian Hipotesis Uji t}

Uji t untuk menguji pengaruh variabel bebas secara parsial terhadap variabel tegantung (Priyanto, 2013). Hasil uji t dapat dilihat pada output coefficients dari hasil analisis regresi linier sederhana. Langkah-langkah uji t sebagai berikut :

a. Merumuskan hipotesis

Ho $: b_{1}=b_{2}$, diduga variabel independen secara parsial tidak berpengaruh terhadap variabel dependen.

$\mathrm{Ha}: \mathrm{b}_{1} \neq \mathrm{b}_{2}$, diduga variabel independen secara parsial berpengaruh terhadap variabel dependen.

b. Menentukan tabel dengan menggunakan tingkat keyakinan 95\%, $\alpha=5 \%$, df 1 (jumlah variabel - 1), df 2 (n-k-1), ( $\mathrm{n}$ adalah jumlah kasus dan $\mathrm{k}$ adalah jumlah variabel independen).

t hitung $=$ koefisien regresi/standar deviasi

1) Bila $t_{\text {tabel }}<t_{\text {hitung, }}$, dan $t_{\text {hitung }}$ variabel independen secara individual tidak bepengaruh terhadap variabel dependen.

2) Bila $t_{\text {hitung }}>t_{\text {tabel }}$, dan $t_{\text {hitung }}$ variabel independen secara individu bepengaruh terhadap variabel dependen.

3) Menentukan variabel independen mana yang mempunyai pengaruh paling dominan terhadap variabel dependen, hubungan ini dapat dilihat dari koefisien regresinya. 


\section{Hasil}

Tabel 1

Hasil Uji Regresi Linier Sederhana

\begin{tabular}{|c|c|c|c|}
\hline \multirow{2}{*}{ Model } & Unstandardized & Coefficients & Standardized Coefficients \\
\hline & $\mathrm{B}$ & Std. Error & Beta \\
\hline (Constant) & 32.316 & 5.559 & 354 \\
\hline
\end{tabular}

Sumber: olahan data

Berdasarkan tabel 1 hasil uji regresi linier sederhana dapat diperoleh koefisien untuk variabel bebas $\mathrm{X}=0.154$ konstanta sebesar 32.316 sehingga model persamaan regresi yang diperoleh :

$\mathrm{Y}=\mathrm{a}+\beta \mathrm{X}+\mathrm{e}$

$\mathrm{Y}=32.316+0.154 \mathrm{X}+\mathrm{e}$

Dari persamaan regresi linier sederhana tersebut dapat disimpulkan sebagai berikut:

1. Nilai konstanta sebesar 32.316 artinya apabila variabel independen insentif (X) bernilai nol (0), maka variabel dependen kinerja (Y) yaitu akan bernilai tetap sebesar 32.316

2. Koefisien regresi variabel insentif bernilai positif sebesar 0.154 artinya apabila variable $X$ mengalami peningkatan sebesar 1 (satu) satuan sedangkan variabel Y yaitu akan mengalami peningkatan sebesar 0.154 .

Tabel 2

Hasil Koefisien Determinasi $\left(\mathbf{R}^{2}\right)$

\begin{tabular}{|l|l|r|r|r|r|}
\hline Model & R & R Square & Adjusted R & Std. Error of the Estimate & Durbin-Watson \\
\hline 1 & .767 & .589 & .585 & 1.68420 & 1.791 \\
\hline
\end{tabular}

Sumber: olahan data

Berdasarkan Tabel 2, nilai koefisien determinasi $\left(\mathrm{R}^{2}\right)$ sebesar 0.589 hal itu berarti bahwa variasi perubahan $\mathrm{Y}$ dipengaruhi oleh perubahan $\mathrm{X}$ sebesar $58.9 \%$. Jadi besarnya pengaruh insentif terhadap kinerja karyawan Hotel Mexsicana Kota Jambi adalah sebesar 58.9\% sedangkan sisanya sebesar $41.1 \%$ dipengaruhi oleh faktor lain diluar penelitian ini. Uji t untuk menguji pengaruh variabel bebas secara parsial terhadap variabel tegantung (Priyanto, 2013: 137). Hasil uji t dapat dilihat pada output coefficients dari hasil analisis regresi linier sederhana. Dengan menggunakan tingkat keyakinan 95\%, $\alpha=5 \%$ dengan derajat kebebasan $(\mathrm{df}) \mathrm{n}-\mathrm{k}-1$ atau 35-1-1 = 33 (n adalah jumlah data, $\mathrm{k}$ adalah jumlah variabel independen). Maka $t_{\text {tabel }}(\alpha=0,05, \mathrm{df}=33)$ diperoleh sebesar 2.034. dari hasil analisis regresi output coefficients dapat diketahui $t_{\text {hitung }}$ dalam tabel sebagai berikut :

Tabel 3

Hasil Uji t

\begin{tabular}{|c|c|c|c|c|c|}
\hline Model & $\begin{array}{l}\text { Unstandardized } \\
\text { B }\end{array}$ & $\begin{array}{l}\text { Coefficients } \\
\text { Std. Error }\end{array}$ & $\begin{array}{c}\text { Standardized Coefficients } \\
\text { Beta }\end{array}$ & $\mathrm{t}$ & Sig \\
\hline $\begin{array}{l}\text { (Constant) } \\
\text { X }\end{array}$ & $\begin{array}{r}32.316 \\
.154\end{array}$ & $\begin{array}{r}5.559 \\
.071\end{array}$ & .354 & $\begin{array}{l}5.813 \\
2.171\end{array}$ & $\begin{array}{l}.000 \\
.002\end{array}$ \\
\hline
\end{tabular}

Sumber: olahan data

Berdasarkan tabel 3, dengan melihat $t_{\text {hitung }}$ dapat diketahui bahwa secara parsial besarnya pengaruh variabel insentif sebesar 2.171, pengujian statistik $t$ dilakukan dengan membandingkan nilai $t_{\text {hitung }}$ dengan $t_{\text {tabel }}$. Dari pengujian maka dijelaskan nilai $t_{\text {hitung }}$ insentif sebesar 2.171 dan $t_{\text {tabel }}$ sebesar 2.034 dari hasil perbandingan maka dapat diketahui $\mathrm{t}_{\text {hitung }}$ lebih besar dari $\mathrm{t}_{\text {tabel }}\left(\mathrm{t}_{\text {hitung }}>\mathrm{t}_{\mathrm{tabel}}\right)$. Maka H0 ditolak dan Ha diterima. Dengan membandingkan besarnya angka taraf signifikan (sig) penelitian dengan taraf signifikan sebesar 0,05 maka $0.002<0,05$ sehingga dapat dikatakan bahwa ada pengaruh signifikan antara insentif terhadap kinerja karyawan Hotel Mexsicana Kota Jambi.

\section{Pembahasan}

Analisis Deskriptif Insentif Karyawan Hotel Mexsicana Kota Jambi

Berdasarkan hasil penelitian yang dilakukan oleh penulis secara keseluruhan rata-rata karyawan Hotel Mexsicana Kota Jambi menilai insentif tersebut berada pada skor 152.05 artinya dapat dikategorikan Sangat Setuju karena berada pada rentang skala 147-175. Adapun penilaian tertinggi ada pada dimensi Kinerja dengan indikator Karyawan yang lebih produktif dalam bekerja dengan rata-rata skor 164 dikategorikan Sangat Setuju.

Analisis Deskriptif Kinerja Karyawan Hotel Mexsicana Kota Jambi 
Berdasarkan hasil penelitian yang dilakukan oleh penulis secara keseluruhan karyawan Hotel Mexsicana Kota Jambi menilai kinerja berada pada skor 155 artinya dapat dikategorikan Sangat Setuju karena berada pada rentang skala 147-175. Adapun penilaian tertinggi ada pada dimensi Pelaksanaan Tugas dengan indikator Saya selalu bediskusi dengan rekan kerja jika menemui kesulitan dalam menyelesaikan pekerjaan dengan rata-rata skor 168 dikategorikan Sangat Setuju.

Analisis Verifikatif Insentif Terhadap Kinerja Karyawan Hotel Mexsicana Kota Jambi

Secara parsial terdapat pengaruh insentif terhadap kinerja karyawan Hotel Mexsicana Kota Jambi. Hal ini ditunjukkan dengan Nilai $t_{\text {hitung }}$ insentif sebesar 2.171 dan $t_{\text {tabel }}$ sebesar 2.034 dari hasil perbandingan maka dapat diketahui $t_{\text {hitung }}$ lebih besar dari $\mathrm{t}_{\text {tabel }}\left(\mathrm{t}_{\text {hitung }}>\mathrm{t}_{\text {tabel }}\right)$. Maka H0 ditolak dan Ha diterima. Dengan membandingkan besarnya angka taraf signifikan (sig) penelitian dengan taraf signifikan sebesar 0,05 maka $0.002<0,05$ sehingga dapat dikatakan bahwa ada pengaruh signifikan antara insentif terhadap kinerja karyawan Hotel Mexsicana Kota Jambi.

\section{Simpulan}

Berdasarkan pembahasan pada bab-bab sebelumnya maka dapat ditarik kesimpulan sebagai berikut:

1. Rata-rata karyawan Hotel Mexsicana Kota Jambi menilai insentif tersebut berada pada skor 152.05 artinya dapat dikategorikan Sangat Setuju karena berada pada rentang skala 147-175 sedangkan Rata-rata karyawan Hotel Mexsicana Kota Jambi menilai kinerja berada pada skor 155 artinya dapat dikategorikan Sangat Setuju karena berada pada rentang skala 147-175

2. Secara parsial terdapat pengaruh insentif terhadap kinerja karyawan Hotel Mexsicana Kota Jambi. Hal ini ditunjukkan dengan Nilai thitung insentif sebesar 2.171 dan ttabel sebesar 2.034 dari hasil perbandingan maka dapat diketahui thitung lebih besar dari ttabel (thitung > ttabel). Maka H0 ditolak dan Ha diterima. Dengan membandingkan besarnya angka taraf signifikan (sig) penelitian dengan taraf signifikan sebesar 0,05 maka 0.002 $<0,05$ sehingga dapat dikatakan bahwa ada pengaruh signifikan antara insentif terhadap kinerja karyawan Hotel Mexsicana Kota Jambi

\section{Daftar Pustaka}

Algifari. 2009. Statistik Induktif. Edisi Kedua. Yogyakarta.

Answar Prabu Mangkunegara. 2010. Evaluasi Kinerja Sumber Daya Manusia. Refika Aditama. Bandung.

Answar Prabu Mangkunegara. 2011. Manajemen Sumber Daya Manusia Perusahaan. Remaja Rosdakarya. Bandung.

Fahrul Budi Santoso. 2016. Pengaruh Insentif Terhadap Kinerja Karyawan Pada PT. Swadarma Sarana Informatika. Jurnal Ilmu Manajemen Ekonomi. Volume 4, Nomor 8

Fandy Gunawan. 2017. Pengaruh Insentif Terhadap Kinerja Pegawai Pada Kantor Sekretariat DPRD Provinsi Banten. Jurnal Ilmu Manajemen Ekonomi dan Bisnis. Volume 2, Nomor 3

Hajrawati Hamka. 2018. Pengaruh Insentif Terhadap Kinerja Karyawan (Studi Karyawan Tetap Pada Pt. Telkom Grapari Kendari). Jurnal Ilmu Manajemen Ekonomi dan Bisnis. Volume 4, Nomor 10.

Hani, Handoko. 2015. Manajemen Personalia dan Sumber Daya Manusia. Yogyakarta: BPFE.

Hasibuan, S.P. 2013. Manajemen Sumber Daya Manusia. Edisi Revisi PT. Bumi Aksara. Jakarta.

Hasibuan, S.P. 2014. Organisasi Dan Motivasi. Jakarta: PT Bumi Aksara.

Jusuf Soewandi, 2012. Pengantar Metode Penelitian, Jakarta: Mitra Wacana Media.

Lamatenggo, Nina. 2012. Teori Kinerja dan Pengkurannya. Jakarta: PT Bumi Aksara.

Mudrajad Kuncoro, Ph. D. 2013. Metode Riset Untuk Bisnis Dan Ekonomi Bagaimana Meneliti Dan Menulis Tesis. Edisi 4. Jakarta: Erlangga.

Priyanto, Dwi. 2013. Data Statistik. Cetakan Pertama. Yogyakarta : Mediakom.

Siswanto, 2017. Pengantar Manajemen. Jakarta: PT Bumi Aksara.

Sugiyono, 2010. Statistik Untuk Penelitian, Bandung: Al Fabeta.

Sugiyono. 2010. Manajemen Sumber Daya Manusia. Penerbit Gramedia. Jakarta.

Syekh, Sayid. 2011. Pengantar Statistik Ekonomi Dan Sosial. Gaung Persada : Jakarta.

Umar, Husein. 2009. Metode Penelitian. Edisi Kedua. Jakarta: Rajawali Press.

Wibowo. 2009. Manajemen Kinerja. Jakarta: Raja Grafindo Persada 